urbanization, education, and the impact of Christianity. Professor Brown, in his foreword, points out that the purpose of the volume 'is to illuminate some of the basic realities and situations prevailing and to analyse selected developments and issues in contemporary Africa'. He admits that some areas in Africa, and some important topics-such as political developments in British East Africa, the role of Islam in sub-Saharan Africa, the question of Asian influence-are ignored or only incidentally considered. Limitations of space and the complexity and diversity of the African scene have made some gaps inevitable; he expresses the hope, however, that the book will 'contribute to our understanding and ... stimulate further study ... 2 This hope has every chance of being fulfilled, for, within the limits imposed, the authors of the various studies have handled their material with skill and insight and, being all authorities in their several fields, have presented illuminating and stimulating accounts of many aspects of African life, culture, and development.

\title{
Grants for Colonial Historical and Administrative Research
}

ON the recommendation of the Colonial Social Science Research Council, the British Colonial Office proposes to make available one or two small grants from Colonial Development and Welfare funds to enable graduates who have already completed or are well advanced in a piece of historical or administrative research in the Colonial field to visit a Colonial territory in order to complete their research work. These grants will apply only to studies relating to those territories for which the Secretary of State for the Colonies is responsible to Parliament, but general studies which relate to Commonwealth countries as well as to Colonial territories would also be considered. The subject of the proposed research must contribute to the understanding of present-day problems or circumstances in a Colonial territory or territories. Grants will normally be limited to a period not greater than six months.

The grants will be made after the interview of selected applicants in October 1959. The qualifications required of candidates are a good honours degree in modern history or another relevant subject or school, and evidence of research work carried out or in progress in Colonial history or administration. Candidates may be required to submit to a medical examination.

Graduates wishing to apply for the grants should proceed as follows :

(i) Write for an application form to the Secretary, Colonial Social Science Research Council, Room S. 613, Colonial Office, Sanctuary Buildings, Great Smith Street, London, S.W. x.

(ii) Complete the application form and give it to their academic supervisor who should be asked to add a recommendation and to forward the application form direct to the Secretary of the Colonial Social Science Research Council before is August 1955. The application should include an outline of the proposed research.

It will be a condition of the grant that a copy of the report embodying the results of the research should be submitted to the Secretary of the Colonial Social Science Research Council; and that a copy of papers or theses written as a result of it should be presented to the Colonial Office Library. 